\title{
Fuel and stand conditions in an isolated, unmanaged forest landscape in central Oregon
}

\author{
Sharon STANTON ${ }^{1 *}$, Karen B. ARABAS ${ }^{2}$ \\ ${ }^{1}$ Biology Department, Portland State University, Portland, Oregon, USA \\ ${ }^{2}$ Department of Environmental and Earth Science, Willamette University, 900 State Street, 97301 Salem, Oregon, USA
}

Keywords:

fuels /

coarse woody debris /

fire hazard /

old-growth forest

(Received 18 July 2008; accepted 19 November 2008)

Mots-clés :

Combustibles /

déchets de bois grossiers /

risque d'incendie /

forêts anciennes

\begin{abstract}
- Mature, unmanaged forests in western North America provide important reference conditions for managers, yet little is known about fuel composition and the factors that influence fuel accumulation in such stands. Our objectives were to characterize fuels in a passively managed landscape of dry forests in central Oregon and identify environmental factors influencing fuel accumulation.

- Ordination techniques and analysis of variance revealed no statistical differences in total fuel loads across a wide range of environmental conditions.

- Individual fuel size classes, however, did vary by stand location and composition. Interior stands had more 1- to 100-h fuels and snags than stands at or near the edge, stands dominated by ponderosa pine had fewer small-diameter fuels and snags, lodgepole pine stands had more 1-h fuels and snags, and white fir stands had more 10-h fuels, duff, and snag basal area.

- Tree species, density and age, and years since last fire were the most important environmental variables, explaining $23 \%$ of the variation in fuels.

- Our results present further evidence that fuel composition is highly variable at many spatial and temporal scales. They also provide useful baseline information for managers of fire-prone western forests.
\end{abstract}

Résumé - Combustible et conditions stationnelles dans un paysage forestier isolé et non géré du centre de l'Oregon.

- Les forêts matures et non gérées de l'Ouest Américain fournissent des situations de référence importantes pour les gestionnaires. Cependant, il n'y a que peu d'informations sur la nature des combustibles et des facteurs qui influent sur l'accumulation de combustible dans ces peuplements. Nos objectifs étaient de caractériser la charge en combustible dans un paysage forestier non géré du centre de l'Oregon et d'identifier les facteurs environnementaux modulant l'accumulation de combustible.

- Des techniques d'ordination et une analyse de variance n'ont révélé aucune différence statistique des charges de combustibles dans un large éventail de conditions stationelles.

- Les charges en combustible variaient cependant suivant la localisation des peuplements et leur composition. Les zones internes des peuplements présentaient plus de charge en combustible de dimensions moyennes et de souches que les lisières. Les peuplements dominés par Pinus ponderosa présentent moins de combustible de faible diamètre et de chicots par rapport à ceux de Pinus contorta. Enfin, les peuplements d'Abies concolor ont plus de combustibles de faible diamètre, et de chicots.

- Les espèces d'arbres, la densité et l'âge et le délai depuis le dernier incendie ont été les variables les expliquant la plus forte part de la variabilité de charge en combustible $(23 \%)$.

- Nos résultats démontrent une fois de plus que la composition du combustible est très variable à plusieurs échelles spatiales et temporelles. Ils fournissent également des données de référence utiles pour les gestionnaires des forêts de l'ouest sujettes aux incendies.

\footnotetext{
* Corresponding author:sstanton@pdx.edu Current Address: Laboratory of Plant Ecology, Kasteelpark Arenberg 31, Bus 2435, 3001 Heverlee, BE, USA.
} 


\section{INTRODUCTION}

Management practices such as fire exclusion and timber harvesting following European settlement of western North America have caused remarkable changes in forest structure and composition (Belsky and Blumenthal, 1997; Cooper, 1960; Covington and Moore, 1994; Weaver, 1959). These changes have altered fire ecology, led to unprecedented fuel accumulations (Harmon et al., 1986; Stephens 2004) and an increasing risk of catastrophic wildland fire (Agee, 1998; Hessburg et al., 2000; Hessburg and Agee, 2003; Moore et al., 1999). Researchers have demonstrated the ecological importance of snags and coarse woody debris (CWD) for structural diversity and wildlife management issues (e.g., Bull et al., 1997; Harmon et al., 1986; Rabe et al., 1998), and many studies have evaluated the effectiveness of fuel reduction treatments in managed forests following prescribed burning, chemical application, or thinning (e.g., Agee and Skinner, 2005; Bilgili, 2003; Brose and Wade, 2002; Stratton, 2004). Such management techniques intend to mimic the role of fire and restore forest structure and function to historical levels, yet little is known about fuels and ecosystem functioning in natural, unmanaged landscapes (Weatherspoon and McIver, 2000).

Few studies have assessed stand-level fuel loads within large, variable, and unmanaged landscapes. Stephens (2004) found fuel loads in mixed conifer stands in Baja, California were lower than those published for comparable managed forests in the western United States. Using a similar comparison, Stephens (2004) noted a greater variability in fuel loads and a patchy distribution of snags in the unmanaged stands. Barbour et al. (2002) quantified relic old-growth stand conditions in the Lake Tahoe Basin and found no significant differences in snag density and biomass of CWD among four stands differing in tree species dominance.

Several studies describe fuel composition in mature, managed forests. Harrington (1981) estimated fuel loads in ponderosa pine forests (Pinus ponderosa) in Arizona and compared post-prescribed burn fuel loads in mature, open stands to those in young, dense stands. There was no difference in total fuel loads between mature and young stands, but young stands tended to have more CWD (>7.6 cm diameter) and fewer fine fuels $(<3 \mathrm{~cm}$ diameter). Robertson and Bowser (1999) assessed CWD in mature ponderosa pine stands in Colorado in an effort to define old-growth forest conditions. They found the volume of CWD was highly variable across the landscape and generally lower than those reported in other stands or forest types resulting from past anthropogenic disturbance at the study site (Robertson and Bowser, 1999). DeLong and Kessler (2000) compared fuels in remnant patches of sub-boreal forest to the surrounding matrix of burned patches. They found highly variable CWD volumes and were unable to discriminate fuel loads among stand types. DeLong and Kessler (2000) also noted lower CWD volumes in harvested lodgepole pine stands (Pinus contorta) compared to similarly aged post-fire stands, suggesting that the processes leading to current stand composition play a critical role in fuel accumulation.

Other studies have evaluated coarse woody debris as a means to characterize the structure and ecosystem value of old-growth stands. Stephens et al. (2007) investigated CWD in unmanaged, old-growth Jeffrey pine (Pinus jeffreyi) stands in northwestern Mexico that experience frequent, low-moderate severity fires and found greater amounts of CWD compared to xeric, managed ponderosa pine forests in the western United States. Spies et al. (1988) evaluated log and snag volume and biomass in old-growth Douglas-fir forests (Pseudotsuga menziesii) in the Pacific Northwest. They found older stands have more CWD, but extreme variability in CWD made it difficult to model fuel accumulation rates in mature stands. For young stands (< 150 years old), Spies et al. (1988) suggest disturbance history is the strongest predictor of CWD composition.

Anthropogenic disturbances altering natural processes in a forested ecosystem may ultimately influence fuel inputs. A better understanding of fuel accumulation processes in unmanaged landscapes will allow for comparison to managed ecosystems. Old-growth forests under natural conditions are becoming increasingly rare and provide reference conditions both for quantifying anthropogenic changes to surrounding forests and restoration efforts. Our study site includes a range of forest types, stand structures, topography, and disturbance histories within a single landscape that has no history of active management. While surrounding forests have experienced extensive management (timber extraction, fuel reduction, fire suppression, recreation), our study site consists of forested islands (kipukas) isolated within a large lava flow and shows no evidence of such management practices. This unique site provides an opportunity to identify which environmental variables most strongly influence natural fuel load accumulations, yet in an area small enough to exclude the confounding influence of climate (short and long term) (Arabas et al., 2006; Pohl et al., 2002).

Our objectives were to characterize fuel composition in a relatively unmanaged landscape of dry forests in central Oregon and identify the environmental factors influencing fuel accumulation in different stand types. Specific questions we addressed were: (i) How do fuel loads differ according to stand type (dominant tree species)? (ii) Which environmental variables (e.g. topography, stand age and density, understory composition) most strongly influence fuel accumulation? (iii) Do the environmental variables that influence fuel loads differ among stand types?

\section{METHODS}

\subsection{Study area}

The study site is located within the Newberry National Volcanic Monument (NNVM) in the Deschutes National Forest in central Oregon, USA (Fig. 1). It is characterized by 11 kipukas (forested islands) isolated among shallow, mid-Holocene lava flows. Kipuka areas range from 0.4 to $113 \mathrm{ha}$, with maximum elevations from 1590 to $1820 \mathrm{~m}$. A few logs and stumps on two kipukas resulting from recent fire suppression efforts are the only evidence of anthropogenic disturbance among the sampled kipukas.

The climate of the study area is strongly influenced by the rainshadow effect created by Oregon's High Cascade Mountains located approximately $50 \mathrm{~km}$ to the west. The moisture regime is semi-arid, 


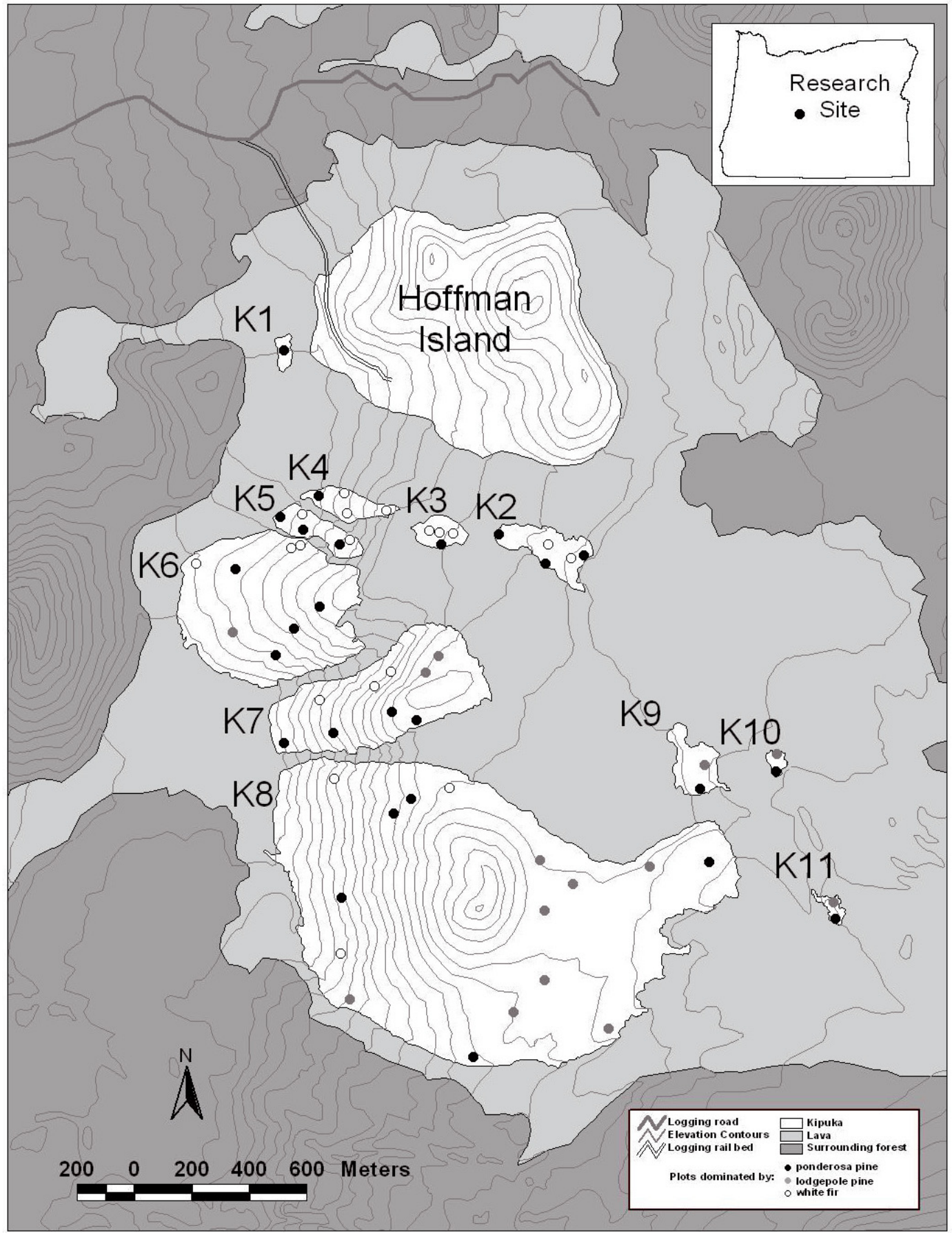

Figure 1. Newberry National Volcanic Monument study site in central Oregon, USA. Sampled kipukas are numbered $K 1-K 11$.

with the majority of precipitation occurring from October to March, typically as snow during the winter. Average annual precipitation between 1971 and 2002 was $\approx 300 \mathrm{~mm}$ and average temperatures range from a low of $0{ }^{\circ} \mathrm{C}$ in January to a high of $17.3{ }^{\circ} \mathrm{C}$ in July (OCS, 2006).

The kipuka forests are dominated by three tree species with ponderosa pine (Pinus ponderosa var. ponderosa) most common on south-facing slopes. North-facing slopes and interior stands are dominated by white fir-grand fir hybrid (Abies concolor $-A$. grandis). Flat areas are typically covered with dense stands of lodgepole pine ( $\mathrm{Pi}$ nus contorta var. murryana). Lodgepole pine stands are significantly younger than the ponderosa pine or white fir stands (Tab. I). Lodgepole pine stands also have a lower basal area and higher density of trees, saplings, and seedlings.

Historically, fire frequency is higher on the kipukas $(M F R I=$ 6 years) than in the surrounding forest $(M F R I=9$ years) (Arabas et al., 2006). Fire return intervals for the surrounding forest decreased following European settlement, probably as a result of management 
Table I. Mean stand variables (standard deviation) and key understory species for all plots within the three stand types based upon dominant tree species as determined by importance values. $B A=$ basal area.

\begin{tabular}{|c|c|c|c|c|c|}
\hline Stand Type & Age (yrs) & Density (trees/ha) & $B A\left(\mathrm{~m}^{2} / \mathrm{ha}\right)$ & $N$ (plots) & Dominant understory species \\
\hline Ponderosa pine & $176(66)$ & $494(305)$ & $26(25)$ & 25 & $\begin{array}{c}\text { Arctostaphylos patula } \\
\text { Ceanothus velutinus }\end{array}$ \\
\hline White fir & $168(35)$ & $1369(1678)$ & $26(25)$ & 19 & $\begin{array}{c}\text { Chimophila umbellate } \\
\text { Purshia tridentate } \\
\text { Ribes cereum }\end{array}$ \\
\hline Lodgepole pine & $93(26)$ & $6978(4241)$ & $3(8)$ & 14 & $\begin{array}{l}\text { Purshia tridentate } \\
\text { Ribes cereum }\end{array}$ \\
\hline
\end{tabular}

Bold face indicates significant difference from other groups indicated by ANOVA $(p<0.01)$.

activities and fire suppression. In contrast, Arabas et al. (2006) report that the MFRI on the kipukas shows no significant change following European settlement, suggesting that stand dynamics continue at historic levels and the study area represents relatively natural forest conditions.

\subsection{Sampling strategy}

Our data were derived from 58 plots established to inventory fuels and collect environmental information summarizing local forest structure and general site conditions. Plot locations were subjectively stratified to ensure the sampling of all stand types present on each kipuka (Fig. 1). We used aerial photos and ground surveys to delineate stand boundaries and locate the approximate center of each to establish plots. Each plot location was assigned UTM coordinates using a GPS to facilitate comparisons with the nearest trees with known fire scar dates (Arabas et al., 2006). Plots sizes varied from $15 \mathrm{~m}^{2}$ to $50 \mathrm{~m}^{2}$, encompassing the minimal area needed to include a sample of at least 20 live trees $>4 \mathrm{~cm}$ dbh (diameter at breast height, $1.4 \mathrm{~m}$ ).

\subsection{Fuel loads}

We measured surface fuel loads in each plot using the planar intercept method (Brown et al., 1982). Total transect length was $15 \mathrm{~m}$; fuels in the 1-h size class $(0-0.64 \mathrm{~cm}$ diameter $)$ were sampled from 0 $2 \mathrm{~m}$ along each transect; 10 -h fuels $(0.65-2.54 \mathrm{~cm})$ from $0-3 \mathrm{~m}$; 100 $\mathrm{h}$ fuels $(2.55-7.62 \mathrm{~cm})$ from $0-5 \mathrm{~m}$; and $1000-\mathrm{h}$ fuels $(>7.62 \mathrm{~cm})$ were sampled from 1-15 m. We measured litter and duff depth at three points along each transect at 0,3 , and $6 \mathrm{~m}$. Litter samples were collected from each transect and oven dried to obtain bulk density measurements. Our calculations of fuel biomass followed the procedures of Brown et al. (1982). We estimated snag densities and used dbh to calculate the basal area $\left(\mathrm{m}^{2} / \mathrm{ha}\right)$ of all snags in each plot.

\subsection{Environmental variables}

Several environmental variables known to influence fuel loads were sampled in each plot. All plots were assigned a forest edge, forest interior, or intermediate location on each kipuka to account for differences in light levels and its effects on overstory and understory species composition (Chen et al., 1995; Hrinkevich, 2005). We noted slope aspect and angle for each plot to further account for the influence of insolation and moisture availability on species composition (Hadley, 1994; Wales, 1972). Our environmental data also included counts of live and dead trees $(d b h \geq 4 \mathrm{~cm})$, saplings $(>1.4 \mathrm{~m}$ tall, but $<4 \mathrm{~cm} \mathrm{dbh})$ and seedlings $(<1.4 \mathrm{~m}$ tall) for each species present. These data were used to calculate importance values, basal area, and density, which are expected to influence the accumulation rate of woody debris and litter on the forest floor and snag density. We used four $1 \mathrm{~m}^{2}$ quadrats per plot to estimate percent cover and richness of understory plants.

We estimated tree ages by removing increment cores $30-50 \mathrm{~cm}$ from the base of all live trees ( $>4 \mathrm{~cm}$ diameter at breast height $(\mathrm{dbh})$ and $>1.4 \mathrm{~m}$ tall) within each plot. Increment cores were mounted and sanded following standard dendrochronological procedures (Stokes and Smiley, 1996) and samples were crossdated using a combination of skeleton plotting and the list method (Yamaguchi, 1991) drawing on marker years identified by Pohl et al. (2002).

Arabas et al. (2006) provided fire history information, including years since the last major fire and mean fire return interval for each stand in the study site. We define major fires as those intense enough to scar trees or logs, or replace entire stands.

\subsection{Data analysis}

\subsubsection{Comparisons of fuel loads among stand types}

Analysis of variance (ANOVA) was used to compare mean fuel loads among plot locations (edge, interior, or intermediate) and stand types (ponderosa pine, white fir, or lodgepole pine). We then applied Bonferonni post-hoc tests to statistically significant variables to identify which locations or stand types differed from each other. We used indirect gradient analysis (principal components analysis or PCA) to identify any obvious patterns in fuel distribution among the plots. PCA is an unconstrained, indirect gradient analysis that reveals the covariance structure within the fuel data and identifies the amount of variability in the fuels that can be interpreted with subsequent direct gradient analysis. PCA identifies correlations among all of the fuel data for all of the plots simultaneously (covariance), revealing which plots are most similar to each other in fuel composition (covariance structure). PCA results allow us to determine if there are predictable patterns in fuels among the plots that can be explained by some measurable environmental gradient (e.g., do plots with older trees tend to have more coarse fuels than younger plots). PCA reveals relationships among the plots using only dependent fuel data, therefore it does not directly identify which environmental variables are responsible for those relationships. 


\subsubsection{Influence of environmental variables on fuel loads and differences among stand types}

We used redundancy analysis (RDA) to quantify and compare the influence of several environmental variables on fuel loads and among the stand types. RDA is a constrained (direct) gradient analysis that identifies which linear combinations of environmental variables best explain the variation in fuel loads among plots and to approximate the distributions of different fuel types along a measured environmental gradient (ter Braak, 1986). RDA differs from PCA in that it is constrained by independent environmental variables added by the researcher. PCA axes reflect the dominant gradients in fuel covariance, while the RDA axes correspond to gradients in fuel composition that have the strongest correlations with the environmental variables. RDA also allowed us to compare the different environmental factors that may drive fuel loads and composition among the different stand types at NNVM by including dominant tree species as a covariate.

We used a forward-selected RDA to determine which environmental variables accounted for the greatest amount of variance in the distribution of fuels and to reduce multicollinearity among the independent environmental variables (CANOCO v.4.0, Ter Braak, 1997). This iterative process selects variables that uniquely and significantly $(p \leq 0.05)$ explain variation in the distribution of fuels. The significance of each added variable and the final canonical axes were verified using Monte Carlo permutation tests with 999 unrestricted permutations ( $p \leq 0.05$ ). We omitted 1000 -h fuels from the RDA because they explained very little of the variation in fuels in the PCA.

All fuel variables were square-root transformed to correct for skewed distributions and to avoid domination by the larger fuel types and standardized to account for the different measurement units (e.g. biomass for ground fuels and basal area for snags). Environmental data were either square-root transformed to normalize skewed distributions and standardized using $z$-scores to account for inconsistency in units of measurement (e.g. count data versus area). We dummy coded categorical variables, such as plot location and dominant tree species, for use in ordination analyses.

\section{RESULTS}

\subsection{Fuel load and snag comparisons among stand types}

Fuel loads were highly variable across the study site (Tab. II and Fig. 2). Larger fuel sizes (100- and 1000 -h) had the largest standard deviations and ranges (Tab. II). Analyses of variance revealed no significant difference in total fuel loads among plot locations or dominant species, but there were differences within specific fuel sizes (Tab. III). Interior plots had more snags, 1-, 10-, and 100-h fuels, and intermediately located plots had the highest litter accumulation and more snags than edge plots (Tab. III). Plots dominated by lodgepole pine had greater loads of 1-h fuels and higher snag density (Tab. III). Fir plots had significantly greater 10-h fuels, duff, and snag basal area than lodgepole or ponderosa pine plots. Plots dominated by ponderosa pine had significantly fewer 100-h fuels (Tab. III).

Principal components analysis (PCA) illustrated that fine fuels explained the greatest amount of variation in fuel composition among all of the plots. Axis I reflected 10- and 100-h fuels (species scores $=-0.80$ and -0.77 respectively) and axis
Table II. Descriptive statistics for fuel loads and environmental data.

\begin{tabular}{lc}
\hline Fuel loads & Mean (std. dev.) \\
\hline 1 -h fuels $(\mathrm{Mg} / \mathrm{ha})$ & $0.2(0.1)$ \\
$10-\mathrm{h}$ fuels $(\mathrm{Mg} / \mathrm{ha})$ & $0.7(0.4)$ \\
$100-\mathrm{h}$ fuels $(\mathrm{Mg} / \mathrm{ha})$ & $0.9(0.8)$ \\
$1000-\mathrm{h}$ fuels $(\mathrm{Mg} / \mathrm{ha})$ & $17.7(21.7)$ \\
Litter $(\mathrm{Mg} / \mathrm{ha})$ & $0.02(0.01)$ \\
Duff $(\mathrm{Mg} / \mathrm{ha})$ & $6.1(4.4)$ \\
Snag basal area $\left(\mathrm{m}^{2} / \mathrm{ha}\right)$ & $7.2(7.6)$ \\
Snag density (\#/ha) & $443(766)$ \\
Dead sapling density (\#/ha) & $1695(5633)$ \\
\hline Environmental variables & \\
\hline Location of stand on kipuka & Edge $n=14$, Interior $n=19$, \\
& Intermediate $n=25$ \\
Dominant tree species & Ponderosa pine, white fir, \\
& lodgepole pine \\
Tree basal area (m $\left.{ }^{2} / \mathrm{ha}\right)$ & Mean $($ std. dev.) \\
Stand density (trees/ha) & $24.6(27.1)$ \\
Tree age (years) & $2427(3508)$ \\
Live seedling density (\#/ha) & $152(60)$ \\
Live sapling density (\#/ha) & $806(1434)$ \\
Understory vegetation richness & $1447(3988)$ \\
& $3.6(2.7)$ \\
Slope aspect & Range \\
Slope angle & $10-360^{\circ}$ \\
Time since last recorded fire (years) & $0-30^{\circ}$ \\
\hline
\end{tabular}

Italics indicate variables identified by PCA and forward-selected RDA as explaining a significant amount of the variation in fuel composition.

II represented 1-h fuels (species score $=0.64$ ). The first two principal components explained more than half of the variance in fuel composition (Fig. 2).

\subsection{Influence of environmental variables on fuel loads}

Redundancy analysis identified tree species, density and age, and years since last fire as significant explanatory variables for fuel distributions among the plots (Fig. 3). The species-environment correlations $\left(\lambda_{1}=0.75, \lambda_{2}=0.54\right)$ indicate the measured environmental variables explained the majority of the covariance structure in fuel composition. Eigenvector length and orientation suggest that duff, snags, and 10-h fuels explained the greatest amount of variance (20\%) in fuel composition among plots when the ordination is constrained by environmental variables (Fig. 3). Fuels in the 1-h size class significantly explained additional variance $(6 \%)$ in fuel composition (Fig. 3).

Inter-set correlations (IC) reflect the strength of the relationship between the environmental variables and the ordination axes. Axis I indicated that stand basal area $(I C=0.53)$ and years since the last major fire $(I C=0.36)$ explained the greatest amount of variation in the fuel loads. The proximity of the vectors for basal area and time since fire indicates a strong correlation between these two environmental variables. Stands that have not burned recently tended to have high basal area. 
Table III. Mean (std. dev.) fuel loads (Mg/ha) and snag basal area $\left(\mathrm{m}^{2} / \mathrm{ha}\right)$ and density (\#/ha), and ANOVA results by stand locations and dominant species. ANOVA compared each fuel class among the three different locations and the three dominant stand types. Stand types designated by dominant species calculated using Importance Values.

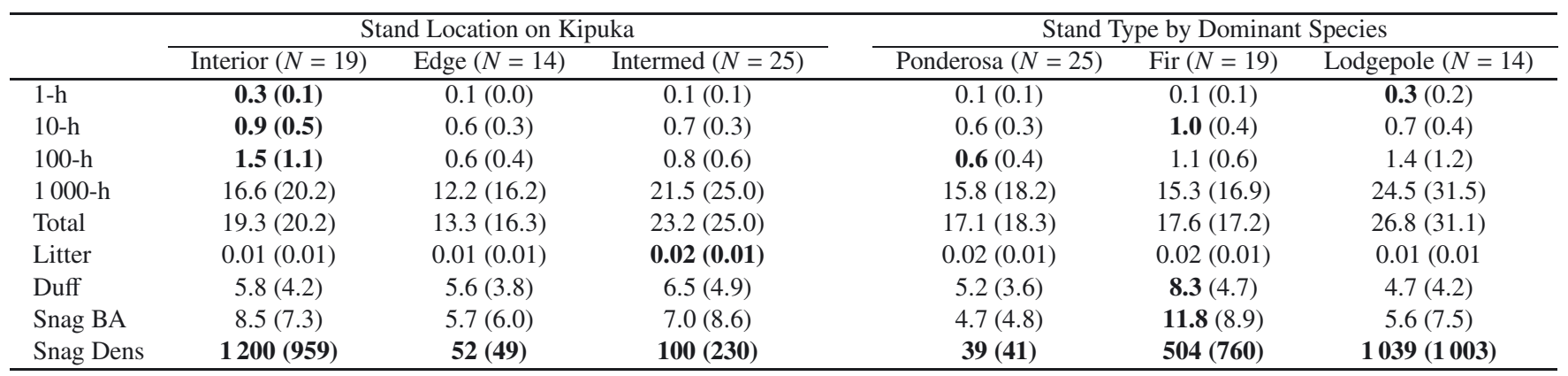

Bold face indicates a significant difference $(p<0.05)$ in that fuel type from the other stand locations or types.

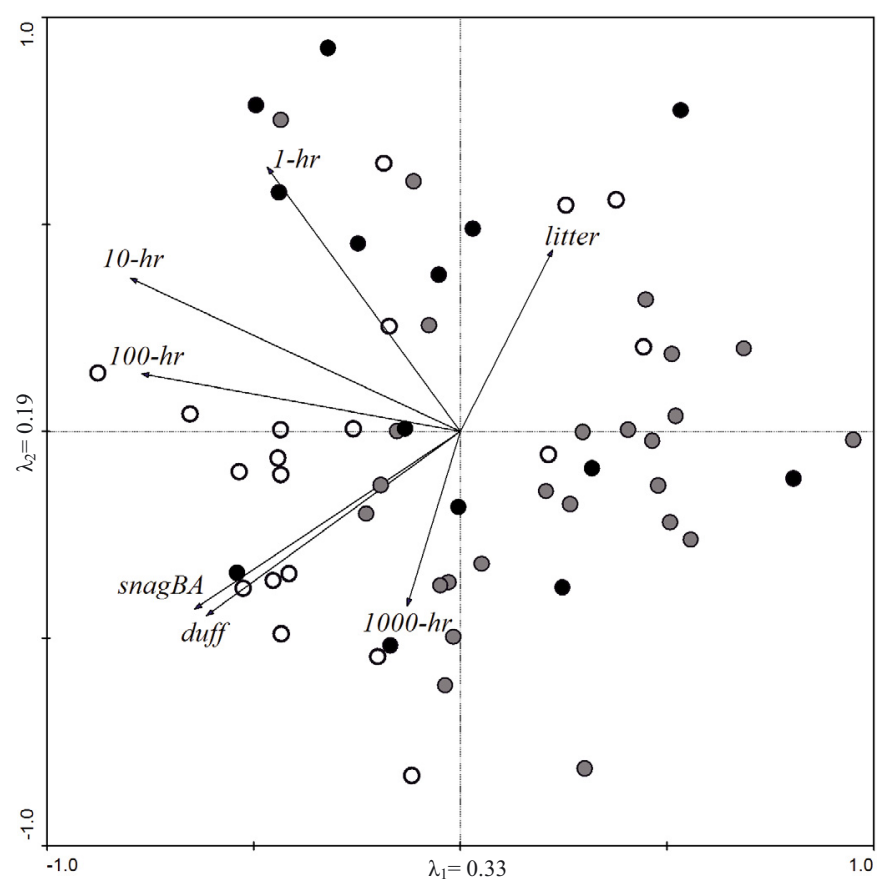

Figure 2. PCA biplot showing the covariance structure of fuel loads among all plots sampled at NNVM. Black circles represent plots dominated by lodgepole pine; gray circles are ponderosa pine; open circles are fir. Vector lengths correspond to species scores, reflecting the strength of the relationship between each fuel class and the axes. Plots located near the end of a vector have high amounts of that fuel class.

The small eigenvalue (0.06) for the second axis indicated stand density and tree age were not strong indicators of fuel composition across the study site once basal area and years since last fire (Axis I) are accounted for. Plot position (edge versus interior) on the kipukas was not a significant environmental variable in the RDA but it was strongly correlated with tree species composition, which caused the strongest separation among plots in the analysis. Interior plots tended to have more



Figure 3. RDA diagram showing the relationship between environmental variables and fuel loads at NNVM. Black circles are plots located in kipuka interiors; gray circles are in intermediate locations; open circles are plots located on kipuka edges. Dashed lines are environmental variable vectors and solid lines are fuel load vectors; vector length signifies the strength of that variable along the axes and vector proximity indicates the degree of correlation between the environmental variable and the fuel class.

1-h fuels and higher stand density, while edge plots tended to have older trees at lower density.

\subsection{Environmental variables and stand type}

Redundancy analysis separated the plots into five groups (I) pure lodgepole pine, (II) large and mature white fir, (III) pure 
Table IV. Comparison of mean woody fuel loads (Mg/ha) and snag densities from coniferous forests throughout western North America. Coarse woody debris (CWD) definitions differ among studies. This study and Kauffman and Martin include logs $>7.62 \mathrm{~cm}$; Stephens and Youngblood et al. $>15 \mathrm{~cm}$; Robertson and Bowser $>10 \mathrm{~cm}$ diameter.

\begin{tabular}{|c|c|c|c|c|c|c|c|}
\hline Source & Location and manag & ent history & $\begin{array}{c}1-\mathrm{h} \\
(\mathrm{Mg} / \mathrm{ha})\end{array}$ & $\begin{array}{c}10-\mathrm{h} \\
(\mathrm{Mg} / \mathrm{ha})\end{array}$ & $\begin{array}{c}100-\mathrm{h} \\
(\mathrm{Mg} / \mathrm{ha})\end{array}$ & $\begin{array}{c}\text { CWD } \\
(\mathrm{Mg} / \mathrm{ha})\end{array}$ & $\begin{array}{l}\text { Snags } \\
(\# / \text { ha) }\end{array}$ \\
\hline This study & Central Oregon & Unmanaged & 0.2 & 0.7 & 0.9 & 17.7 & 443 \\
\hline Kauffman and Martin (1989) & Sierra Nevada & Managed & $0.2-0.8$ & $1.9-3.0$ & $0.9-3.7$ & $10.7-29.5$ & $\mathrm{n} / \mathrm{a}$ \\
\hline Youngblood et al. $(2006 ; 2008)$ & NE Oregon & Managed & 0.4 & 0.6 & 3.0 & 16.9 & 46 \\
\hline Stephens (2004) & NW Mexico & Unmanaged & 0.1 & 0.8 & 1.2 & 13.8 & 5 \\
\hline Knapp et al. (2005) & Sierra Nevada & Managed & 1.4 & 2.8 & 4.8 & 94.8 & $\mathrm{n} / \mathrm{a}$ \\
\hline Agee and Lolley (2006) & Central Washington & Managed & 1.1 & 2.0 & 3.5 & 11.4 & $\mathrm{n} / \mathrm{a}$ \\
\hline Stephens and Moghaddas (2005b) & Sierra Nevada & Managed & 1.0 & 3.8 & 6.7 & 24.4 & $\mathrm{n} / \mathrm{a}$ \\
\hline Stephens and Moghaddas (2005a) & Sierra Nevada & Managed & $\mathrm{n} / \mathrm{a}$ & $\mathrm{n} / \mathrm{a}$ & $\mathrm{n} / \mathrm{a}$ & 35 & 28 \\
\hline Ganey (1999) & N Arizona & Managed & $\mathrm{n} / \mathrm{a}$ & $\mathrm{n} / \mathrm{a}$ & $\mathrm{n} / \mathrm{a}$ & $\mathrm{n} / \mathrm{a}$ & 5 \\
\hline Barbour et al. (2002) & Lake Tahoe Basin & Unmanaged & $\mathrm{n} / \mathrm{a}$ & $\mathrm{n} / \mathrm{a}$ & $\mathrm{n} / \mathrm{a}$ & $\mathrm{n} / \mathrm{a}$ & 109 \\
\hline Stephens et al. (2007) & NW Mexico & Unmanaged & $\mathrm{n} / \mathrm{a}$ & $\mathrm{n} / \mathrm{a}$ & $\mathrm{n} / \mathrm{a}$ & 16 & $\mathrm{n} / \mathrm{a}$ \\
\hline Robertson and Bowser (1999) & Front Range Colorado & Managed & $\mathrm{n} / \mathrm{a}$ & $\mathrm{n} / \mathrm{a}$ & $\mathrm{n} / \mathrm{a}$ & 3 & $\mathrm{n} / \mathrm{a}$ \\
\hline Robertson and Bowser (1999) & SW Colorado & Managed & $\mathrm{n} / \mathrm{a}$ & $\mathrm{n} / \mathrm{a}$ & $\mathrm{n} / \mathrm{a}$ & 5 & $\mathrm{n} / \mathrm{a}$ \\
\hline
\end{tabular}

ponderosa pine, (IV) smaller ponderosa pine with a fir and lodgepole pine component, and (V) smaller and younger fir) based on relative age and dominance of the three tree species (Fig. 3). The RDA environmental vectors indicated that lodgepole pine plots (group I) are characterized by young trees growing at high density following relatively recent fire. The fuel vectors indicated that lodgepole-dominated plots tended to have high accumulations of 1-h fuels with little duff.

The mature white fir plots (group II) were characterized by old individuals growing at intermediate densities following a prolonged absence of severe fire (Fig. 3). Duff biomass and snag basal area reached their highest values in these plots. Mature fir plots typically had high accumulations of 10- and 100-h fuels, but low amounts of 1000 -h fuels or litter (Fig. 3).

Redundancy analysis differentiated between two distinct groups of ponderosa pine-dominated plots (Fig. 3). The pure ponderosa pine plots (group III) were characterized by low stand density and some of the oldest trees in the study area, but there was a high degree of variation in tree ages among ponderosa pine plots (Fig. 3). Similar to the mature fir plots (II), the mature ponderosa plots had not experienced recent severe fires (Arabas et al. 2006). Plots dominated by pure ponderosa pine had high accumulations of 1000 -h fuels with low to moderate fine fuel accumulations (Fig. 3). The second ponderosa pine group (IV) included younger trees growing at higher densities and mixed with white fir or lodgepole pine. These plots had experienced more recent severe fire than the pure ponderosa plots in group III (Fig. 3). The fuel composition in the mixed ponderosa plots included high accumulations of litter, low snag basal area, duff, and 10-h fuels (Fig. 3). The spread of plots along the 1 -h vector illustrates that there was high variation in 1-h fuels among the plots within this group.

Six white fir plots (group V) differ from the fir plots in group II based on the dominance of young, small-diameter trees located at intermediate positions on smaller kipukas. In contrast to the mature white fir (III), these plots experienced more recent fire and had more litter and less duff, 10- and 100-h fuels, and snag basal area (Fig. 3).

\section{DISCUSSION}

\subsection{Fuel loads and snag densities}

Fuel data from our plots were highly variable but similar to those reported for other western North American conifer forests (Tab. IV). Fuel loads for downed woody debris at NNVM were comparable to those published by Kaufmann and Martin (1989) and Stephens (2004) for Jeffrey pine stands in western North America, and dry forests of northeastern Oregon (Youngblood et al. 2006; 2008). The distribution of 1000 -h fuels at NNVM was bimodal and highly variable, with almost half the study plots having none and the other half having large amounts. Other studies also reported wide ranges in 1000 -h fuel loads, both within and among study sites (Tab. IV). NNVM values were similar to those reported by Stephens et al. (2007) for an unmanaged xeric forest in northwestern Mexico (Tab. IV), but comparisons with other studies are complicated because researchers define CWD differently. The bimodal distribution of CWD at NNVM further compromises multivariate comparisons of 1000-h fuel loads among our plots, therefore their influence on fuel composition at our study site may be underestimated.

Reports of snag densities were also highly variable across studies. Stephens (2004) recorded snag densities ranging from 3.95-5.10 snags/ha, with $35 \%$ of sampled plots having no snags. Robertson and Bowser (1999) reported an average snag density of 11.92 snags/ha in mature ponderosa pine stands in Colorado, with $52 \%$ of plots lacking snags. Youngblood et al. (2006) found more snags in dry forests of northeastern Oregon (46-53 snags/ha), but still less than we recorded in central Oregon (averaging 443 snags/ha, 12\% of plots lacking snags). NNVM snag densities were also higher than those reported by Ganey (1999) for ponderosa pine stands in Arizona (5 snags/ha) and Barbour et al. (2002) for Jeffrey pine in California (109/ha), who used diameter limits and sampled in managed stands. The high snag densities observed at NNVM were likely a function of two factors. First, high mortality was 
common among the dense, young post-fire cohorts of lodgepole pine and fir. Excluding interior plots where these dense stands are typically located reduced average snag density to $86 /$ ha. Second, recent mortality associated with mountain pine beetle may increase the number of snags in plots with older ponderosa or lodgepole pine trees.

\subsection{Fuel loads and snag basal area by stand type}

Neither plot location nor dominant tree species made a significant difference in total fuel loads at NNVM. However, there were differences in individual fuel size classes across stand locations and types. Plots located in kipuka interiors were often dominated by lodgepole pine and had high 1-h fuel loads. Interior plots also had the highest 10-h fuel loads, especially those dominated by mature white fir. Ponderosa pine dominated stands, typically located near the edges or intermediate locations on the kipukas, had significantly lower 100-h fuel loads compared to the lodgepole pine and fir stands. The strong correlation between stand location and type make it difficult to identify which variable plays a stronger role in fuel accumulation.

Lodgepole pine plots shared similar fuel loads as demonstrated by their tight grouping in the RDA diagram. The majority of lodgepole pine stands at NNVM were young, dense postfire cohorts in the process of self-thinning. Unlike larger trees, self-thinning lodgepole pines rarely persist as standing fuel resulting in a low snag basal area. The majority of downed fuels from these small diameter trees were leaf litter and 1-h fuels. High variations in 10- and 100-h fuel classes in the lodgepole pine plots occurred in the few mature stands located on or near the edge of kipukas.

The majority of plots dominated by white fir exhibited lower variability in fuel composition and high accumulations of duff, 10-h fuels and snags compared to other stand types. These fir stands were older and located on more northerly kipukas or on north-facing slopes that have not experienced recent fire. The high snag basal area may be explained by the susceptibility of fir trees to a variety of root diseases and insects and the senescence of mature individuals. Van Wagtendonk et al. (1998) found similar high duff, 10- and 100-h fuel loads for white fir stands in Sierra Nevada. Barbour et al. (2002) also reported higher snag density in white fir than pine or mixed conifer stands near Lake Tahoe. The younger and more southern stands of fir at NNVM burned more recently and therefore had lower accumulations of duff, 10-h fuels and snags. Other studies have demonstrated similar positive correlations between stand age and duff, 10- and 100-h fuels (van Wagtendonk et al., 1998).

The other key difference between the two fir groups was understory composition. The understory of the more mature stands was dominated by Chimophila umbellata, a lowgrowing shade-tolerant species that contributes little to fuel loads. In contrast, Purshia tridentata and Ribes cereum dominated the understory of the younger, more recently burned stands. These disturbance-adapted shrubs more likely contributed to the accumulation of fine fuels such as litter. Under- story composition may also indicate differences in local site productivity, which would influence fuel accumulation rates.

Ponderosa pine plots exhibited high variability in all fuel classes and separated into two distinct groups based primarily on tree age and fire history. The older, pure ponderosa pine plots (group III) that have not experienced recent fire had low accumulations of 1-h fuels. Younger, more dense, ponderosa pine plots (group IV) had greater accumulations of litter and 1-h fuels, less duff, and fewer snags. These results differ from Harrington's (1981) reports of young, dense stands having less litter. The younger ponderosa pine stands at NNVM included a mix of fir and lodgepole pine and occur on the more mesic west or northwest facing slopes. These conditions suggest high litter accumulations may be a function of: (1) higher site productivity, (2) the contribution of large needles and high crown density of ponderosa pine combined with smaller needles and higher stem densities added by the fir and lodgepole pine, and (3) a dead or dying understory of Arctostaphylos patula and Ceanothus velutinus shrubs leading to high local accumulations of litter. Older stands tended to have more duff and snags, and fewer 1-h fuels consistent with more xeric conditions and a lower stand density. Mature stands also included larger canopy openings and have open crown structures that reduce the shedding of needles and twigs characteristic of younger trees.

\subsection{Influence of environmental variables on fuel loads and snags}

No single stand-level environmental variable consistently predicted the accumulation of fuels or snags at NNVM. These results were similar to other studies (Brown and See, 1981; Robertson and Bowser, 1999; Spies et al., 1988) indicating that fuel composition is a function of several factors operating at multiple scales. At NNVM these factors included species dominance, basal area, stand density and age, and time since the last fire, yet the contribution of each of these factors was limited to specific fuel size classes. Stand density was positively correlated with 1-, 10-, and 100-h fuel loads, but had little influence on litter or duff accumulation after accounting for species composition. Duff biomass was more strongly correlated with stand age and basal area and time since last fire. Older stands with larger trees have been accumulating duff and snags over time. Several of the young lodgepole pine stands at NNVM experienced varying degrees of blowdown contributing to the weak overall correlation between stand density and snag abundance.

Litter loads were negatively correlated with all of the tested environmental variables, especially stand basal area and time since the last fire (Fig. 3). Intuitively, the absence of fire would lead to high litter accumulations, but we found the opposite. Mature ponderosa pine plots that had not experienced recent fire had lower litter biomass. This may be explained in part by a history of pandora moth (Coloradia pandora Blake) outbreaks at NNVM. Pandora moths defoliate ponderosa pine trees, removing needle biomass that would contribute to litter loads and lowering fire frequencies (Speer et al. 2001). The 
high litter accumulations in more recently burned plots may result from scorched needle fall following low-severity ground fires (Agee, 2003; Arabas, 1997; Perrakis and Agee, 2006; Stanton, 2007) and the vigorous growth of fire-adapted shrubs in the understory.

\subsection{Environmental variables and stand type}

The environmental variables that influenced fuel composition differ between lodgepole pine stands and ponderosa pine or fir stands. Stand age and basal area, and time since last fire were most strongly correlated with fuel composition in ponderosa pine and white fir plots. In contrast, fuels in lodgepole pine plots appeared to be more strongly controlled by stand density. Our sample size limited us from analyzing each stand type separately to identify directly which environmental variables are most important in the different stand types. In particular, additional studies are needed that include more data from unmanaged lodgepole pine and white fir stands.

\section{CONCLUSIONS}

Fuel composition and the environmental variables that best explain fuel loads differed among the three stand types included in this study, and fuel loads within each stand type were highly variable, making it difficult to generalize across the landscape which environmental variables can be used as key predictors of fuel loads and subsequent fire hazard. The majority of environmental variables we sampled did not contribute significantly to a general explanation of surface fuel or snag accumulation. Topography (slope aspect and elevation) however, appeared to be an important indirect factor because of its role in determining species composition, one of the more important stand variables we identified.

Similar to other studies, our results suggest that variation in surface fuels is too large to be easily explained by independent variables with relatively low variance, or we failed to account for a key explanatory variable. We do not have accurate estimates of insect outbreaks, nor did we include live fuels in our analyses, either of which could influence fuel accumulation across the study site. Additionally, the influence of fire history on fuel accumulation is complex and difficult to identify. Our analysis included only major fires that scarred standing trees or logs. It is likely that low-intensity surface fires have burned in many of our plots, but there is a lack of accurate records to identify when or where those fires occurred. Surface fires would have consumed primarily fine fuels (litter, duff, and 1-h), but low-intensity fires can sometimes increase fuel accumulation through scorching and sapling mortality. Needle loss following low intensity fire may also explain the lack of a correlation between litter loads and time since the last major fire.

Our results support the broad consensus that forest fuel composition in western North America is highly variable at many spatial scales, especially in relatively unmanaged stands (Stephens et al. 2008). Stand composition is often an insufficient estimator of fuel composition and total fuel load data may be an inadequate indicator for wildfire risk. Obtaining accurate fuel load data can be difficult (Westfall and Woodall, 2007) and current methods for estimating fuel loads tend to be general, focusing on patterns in fuel loads while ignoring the processes that govern fuel load dynamics. Several authors note the need for fuel treatments with an ecosystem management approach that considers both patterns and process at multiple spatial scales (Lehmkuhl et al., 2007; McKenzie et al., 2007; Reinhardt et al., 2008; Stephens et al., 2007; Weatherspoon and McIver, 2000), but it remains difficult to assess multiple aspects of stand dynamics such as tree density, insect outbreaks, and species diversity across multiple spatial and temporal scales. If the management goal is to maintain or restore healthy and resilient forests, variation and heterogeneity in fuel composition must be considered along with stand history and the ecosystem processes that led to the observed patterns in forest and fuel composition.

Acknowledgements: The authors would like to thank Keith Hadley and Andrea Lovejoy for their help developing this research. Special thanks to Ed Arabas for creating Figure 1. The field work could not have been completed without the hard work of Evan Larson, Danica Praza, Kate Hrinkevich, Shelley Moore, Ed Arabas, and Michael Leeson. We thank the Deschutes National Forest for access to NNVM.

\section{REFERENCES}

Agee J.K., 1998. The landscape ecology of western forest fire regimes. Northwest Sci. 72: 24-34.

Agee J.K., 2003. Monitoring postfire tree mortality in mixed-conifer forests of Crater Lake, Oregon, USA Nat. Areas J. 23: 114-120.

Agee J.K. and Lolley M.R., 2006. Thinning and prescribed fire effects on fuels and potential fire behavior in an eastern Cascades forest, Washington, USA. Fire Ecology 2: 142-158.

Agee J.K. and Skinner C.N., 2005. Basic principles of forest fuel reduction treatments. For. Ecol. Manage. 211: 83-96.

Arabas K.B., 1997. Fire and vegetation dynamics in the eastern serpentine barrens. Ph.D. dissertation: Pennsylvania State University, State College, PA.

Arabas K.B., Hadley K.S., and Larson E.R., 2006. Fire history of a naturally fragmented landscape in central Oregon. Can. J. For. Res. 36: $1108-1120$.

Barbour M., Kelley E., Maloney P., Rizzo D., Royce E., and Fites-Kaufmann J., 2002. Present and past old-growth forests of the Lake Tahoe Basin, Sierra Nevada, US. J. Veg. Sci. 13: 461-472.

Belsky J.A. and Blumenthal D.M., 1997. Effects of livestock grazing on stand dynamics and soils in upland forests of the interior west. Conserv. Biol. 11: 315-327.

Bilgili E., 2003. Stand development and fire behavior. For. Ecol. Manage. 179: 333-339.

Brose P. and Wade D., 2002. Potential fire behavior in pine flatwood forests following three different fuel reduction techniques. For. Ecol. Manage. 163: 71-84.

Brown J.K., Oberheu R.D., and Johnston C.M., 1982. Handbook for inventorying surface fuels and biomass in the interior west. USDA Forest Service General Technical Report INT-129.

Brown J.K. and See T.K., 1981. Downed woody fuel and biomass in the Northern Rocky Mountains. USDA Forest Service General Technical Report INT-117.

Bull E.L., Parks C.G., and Torgersen T.R., 1997. Trees and logs important to wildlife in the interior Columbia River Basin. USDA Forest Service General Technical Report PNW-GTR-391. 
Chen J., Franklin J.F., and Spies T.A., 1995. Growing-season microclimatic gradients from clearcut edges into old-growth Douglas-fir forests. Ecol. Appl. 5: 74-86.

Cooper C.F., 1960. Changes in vegetation, structure, and growth of southwestern pine forests since white settlement. Ecol. Monogr. 30: 129164.

Covington W. and Moore M.M., 1994. Southwestern ponderosa forest structure: Changes since Euro-American settlement. J. For. 92: 39_ 47.

Deeming J.E., Burgan R.E., and Cohen J.D., 1977. The National FireDanger Rating System. USDA Forest Service GTR INT-39.

DeLong S.C. and Kessler W.B., 2000. Ecological characteristics of mature forest remnants left by wildfire. For. Ecol. Manage. 131: 93-106.

Ganey J.L., 1999. Snag density and composition of snag populations on two national forests in northern Arizona. For. Ecol. Manage. 117: $169-178$.

Hadley K.S., 1994. The role of disturbance, topography, and forest structure in the development of a montane forest landscape. Bull. Torrey Bot. Club 121: 47-61.

Harmon M.E., Franklin J.F., Swanson F.J., Sollins P., Gregory S.V., Lattin J.D., Anderson N.H., Cline S.P., Aumen N.G., Seddel J.R., Lienkaemper G.W., Cromack K., and Cummins K.W., 1986. Ecology of coarse woody debris in temperate ecosystems. Adv. Ecol. Res. 15: 133-302.

Harrington M.G., 1981. Preliminary burning prescriptions for ponderosa pine fuel reductions in southeastern Arizona. USDA Forest Service Research Note RM-402.

Hessburg P.F, Smith B.G., Salter R.B., Ottmar R.D., and Alvarado E., 2000. Recent changes (1930s-1990s) in spatial patterns of interior northwest forests, USA. For. Ecol. Manage. 136: 53-83.

Hessburg P.F. and Agee J.K., 2003. An environmental narrative of Inland Northwest United States forests, 1800-2000. For. Ecol. Manage. 178: 23-59.

Hrinkevich K.H., 2005. Forest edge dynamics in a naturally fragmented landscape in central Oregon. M.S. thesis, Portland State University, Oregon, $108 \mathrm{p}$

Kauffman J.B. and Martin R.E., 1989. Fire behavior, fuel consumption, and forest-floor changes following prescribed understory fire in Sierra Nevada mixed conifer stands. Can. J. For. Res. 19: 455-462.

Knapp E.E., Keeley J.E., Ballenger E.A., and Brennan T.J., 2005. Fuel reduction and coarse woody debris dynamics with early season and late season prescribed fire in a Sierra Nevada mixed conifer forest For. Ecol. Manage. 208: 383-397.

Lehmkuhl J.F., Kennedy M., Ford E.D., Singleton P.H., Gaines W.L., and Lind R.L., 2007. Seeing the forest for the fuel: Integrating ecological values and fuels management. For. Ecol. Manage. 246: 73-80.

McKenzie D., Raymond C.L., Kellogg L.-K.B., Norheim R.A., Andreu A.G., Bayard A.C., Kopper K.E., and Elman E., 2007. Mapping fuels at multiple scales: landscape application of the Fuel Characteristic Classification System. Can. J. For. Res. 37: 2421-2437.

Moore M.M., Covington W.W., and Fule P.Z., 1999. Evolutionary environment, reference conditions, and ecological restoration: a southwestern ponderosa pine perspective. Ecol. Appl. 9: 1266-1277.

Oregon Climate Service (OCS), 2006. Oregon climate zone data (online). Available at: http://ocs.oce.orst.edu.

Perrakis D.D.B. and Agee J.K., 2006. Seasonal fire effects on mixedconifer forest structure and ponderosa pine resin properties. Can. J. For. Res. 36: 238-264.

Peterson N.V. and Groh E.A., 1969. The ages of some Holocene volcanic eruptions in the Newberry Volcano area, Oregon. Ore Geol. 31: 73-87.

Pohl K.A., Hadley K.S., and Arabas K.B., 2002. A 545-year drought reconstruction for central Oregon. Phys. Geogr. 23: 302-320.

Rabe M.J., Morrell T.E., Green H., deVos Jr. J.C., and Miller C.R., 1998. Characteristics of ponderosa pine snag roosts used by reproductive bats in northern Arizona. J. Wildl. Manage. 62: 612-621.
Reinhardt E.D., Keane R.E., Calkin D.E., and Cohen J.D., 2008. Objectives and considerations for wildland fuel treatment in forested ecosystems of the interior western United States. For. Ecol. Manage. (in press).

Robertson P.A. and Bowser Y.H., 1999. Coarse woody debris in mature Pinus ponderosa stands in Colorado. J. Torrey Bot. Soc. 126: 255-267.

Speer J.H., Swetnam T.W., Wickman B.E., and Youngblood A., 2001. Changes in pandora moth outbreak dynamics during the past 622 years. Ecology 82: 679-697.

Spies T.A., Franklin J.F., and Thomas T.B., 1988. Coarse woody debris in Douglas-fir forests of western Oregon and Washington. Ecology 69: 1689-1702.

Stanton S.M., 2007. The fire ecology of mature ponderosa pine (Pinus ponderosa) stands infected with western dwarf mistletoe (Arceuthobium campylopodum). Ph.D. dissertation, Portland State University, Oregon.

Stephens S.L., 2004. Fuel loads, snag abundance, and snag recruitment in an unmanaged Jeffrey pine-mixed conifer forest in Northwestern Mexico. For. Ecol. Manage. 199: 103-113.

Stephens S.L., Fry D.J., Granco-Vizcaino E., Collins B.M., and Moghaddas J.M., 2007. Coarse woody debris and canopy cover in an old-growth Jeffrey pine-mixed conifer forest from the Sierra San Pedro Martir, Mexico. For. Ecol. Manage. 240: 87-95.

Stephens S.L., Fry D.L., and Franco-Vizcaíno E., 2008. Wildfire and spatial patterns in forests in northwestern Mexico: the United States wishes it had similar fire problems. Ecol. Soc. (in press).

Stephens S.L. and Moghaddas J.J., 2005a. Fuel treatment effects on snags and coarse woody debris in a Sierra Nevada mixed conifer forest. For. Ecol. Manage. 214: 53-64.

Stephens S.L. and Moghaddas J.J., 2005b. Experimental fuel treatment impacts on forest structure, potential fire behavior, and predicted tree mortality in a California mixed conifer forest. For. Ecol. Manage. 215: $21-36$.

Stratton R.D., 2004. Assessing the effectiveness of landscape fuel treatments on fire growth. J. For. 102: 32-40.

Stokes M.A. and Smiley T.L., 1996. An Introduction to Tree-Ring Dating. University of Arizona Press, Tucson, Arizona.

Ter Braak C.J.F., 1986., Canonical correspondence analysis: a new eigenvector technique for multivariate direct gradient analysis. Ecology 67: $1167-1179$.

Ter Braak C.J.F., 1998. CANOCO v 3.1 program for canonical community ordination. Agricultural Mathematics Group, Wageningen, The Netherlands.

Van Wagtendonk J.W., Benedict J.M., and Sydoriak W.S., 1998. Fuel bed characteristics of Sierra Nevada conifers. West. J. Appl. For. 13: 73-84.

Wales B.A., 1972. Vegetation analysis of north and south edges in a mature Oak-Hickory forest. Ecol. Monogr. 42: 451-471.

Weatherspoon C.P. and McIver J.D., 2000. A national study of the consequences of fire and fire surrogate treatments. Executive Summary for the Fire and Fire Surrogate Study. Available online: http://frames. nbii.gov/ffs.

Weaver H., 1959. Ecological changes in the ponderosa pine forest of Warm Springs Indian Reservation in Oregon. J. For. 57: 15-20.

Westfall J.A. and Woodall C.W., 2007. Measurement repeatability of a large-scale inventory of forest fuels. For. Ecol. Manage. 253: 171-176.

Yamaguchi D.K., 1991. A simple method for cross-dating increment cores from living trees. Can. J. For. Res. 21: 414-416.

Youngblood A., Metlen K.L., and Coe K., 2006. Changes in stand structure and composition after restoration treatments in low elevation dry forests of northeastern Oregon. For. Ecol. Manage. 234: 143-163.

Youngblood A., Wright C.S., Ottmar R.D., and McIver J.D., 2008. Changes in fuelbed characteristics and resulting fire potentials after fuel reduction treatments in dry forests of the Blue Mountains, northeastern Oregon. For. Ecol. Manage. 255: 3151-3169. 